\title{
Mimosine in Leucaena as a potent bio-herbicide
}

\author{
T.D. Xuan, A.A. ElzaAwely, F. Deba, M. Fukuta, S. Tawata* \\ Department of Bioscience and Biotechnology, Faculty of Agriculture, University of the Ryukyus, Okinawa 903-0213, Japan
}

(Accepted 14 December 2005)

\begin{abstract}
Mimosine [ $\alpha$-amino- $\beta$-(3-hydroxy-4-oxo-1,4-dihydropyridin-1-yl)-propanoic acid] is a major constituent of Leucaena (Leucaena leucocephala de Wit) and responsible for the strong allelopathic potential of the legume tree. Mimosine showed strong herbicidal activities on six plants in a bioassay. All plant parts of Leucaena contain mimosine. The quantity of mimosine in the young leaves and mature seeds was the greatest, 2.66 and $2.38 \%$ of dry weight, respectively, while the quantity in the root xylems and xylems was the lowest: 0.18 and $0.11 \%$ of dry weight, respectively. Younger plant parts of Leucaena contained greater amounts of mimosine than the mature parts. Mimosine released from young parts and the seeds of Leucaena was proportional to the quantity of soaking water. Compared with the mature seeds, other mature parts of the plant did not give any mimosine through exuding. In soil to which mimosine was added, about $60 \%$ of the mimosine was adsorbed in 1-5 days, and only a minor volume of mimosine was decomposed: 5.30 and $0.16 \%$ after 1 and 5 days, respectively. Using a mixture of $\mathrm{FeCl}_{3}$ and mimosine in a 4:6 ratio may be the most effective and economical method of lowering the toxicity of mimosine in Leucaena leaves, giving a safer cattle feed and decreasing the soil toxicity caused by mimosine in areas where Leucaena is grown. On the other hand, the incorporation of mimosine leaves into cultivated soils may be helpful for the biological control of weeds. The findings of this research reveal that mimosine may be useful for the development of bio-herbicides.
\end{abstract}

Mimosine / Leucaena / toxicity / exude / soil / $\mathrm{FeCl}_{3}$ / bio-pesticide

\section{INTRODUCTION}

Allelopathy is defined by Rice (1984) as the direct or indirect harmful or beneficial effects of the donor plant on the target one through the production of chemical compounds that escape into the environment. It includes both detrimental and beneficial interactions between plants through chemicals released by the donor. However, in practice, the term allelopathy is generally used to refer to detrimental plant-plant interaction (Kohili et al., 1998). The importance of allelopathy in agriculture is becoming increasingly recognized, in particular in the biological control of weeds and pests (Rice, 1984). Allelopathy can be successfully utilized as a biological tool in weed and pest management by (1) the transfer of the production of allelopathic genes to crops, (2) enhancement of the production of natural toxins or their products as bio-pesticides through tissue or cell culture, and (3) the use of DNA recombinant technology. To date, very few achievements in (1) and (3) have been reported. Therefore the development of bio-pesticides for eco-friendly sustainable agricultural production is the most promising and feasible.

Leucaena is a leguminous tree that has a tolerance to drought and is distributed widely in subtropical and tropical zones (Fig. 1). In Southeast Asia and Africa, Leucaena is grown for soil erosion prevention and soil improvement (Hong et al., $2003,2004)$. With high annual yield and rich palatable protein

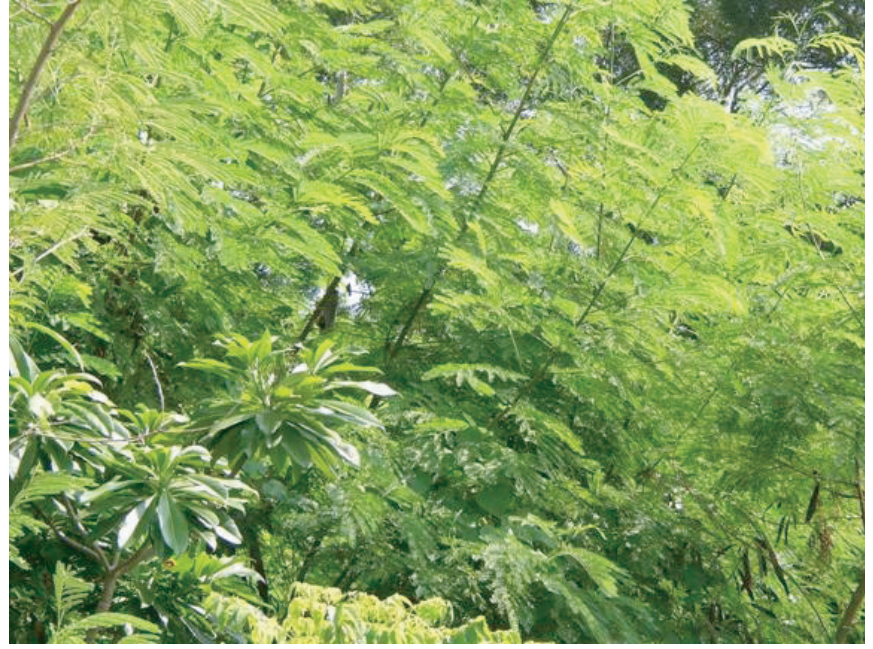

Figure 1. Leucaena trees.

in foliage, Leucaena may resolve the shortage of animal feeds in developing countries. However, this usage is limited due to the presence of a toxic non-protein amino acid, mimosine (Fig. 2), in Leucaena plants (Tawata, 1990). Mimosine has general antimitotic activity that blocks the cell cycle in the large

* Corresponding author: b986097@agr.u-ryukyu.ac.jp 
<smiles>N[C@@H](Cn1ccc(=O)c(O)c1)C(=O)O</smiles>

Figure 2. Chemical structure of mimosine.

G1 phase (Khanna and Lavin, 1993), and inhibits DNA synthesis, which prevents the formation of the replication fork by altering deoxyribonucleotide metabolism (Gilbert et al., 1998). This amino acid may act as tyrosine analogue, which incorporates biologically vital proteins and in turn causes hair loss (Crounse et al., 1962). The ingestion of Leucaena results in alopecia, growth retardation, cataracts and infertility in animals. Mimosine can be converted into DHP [3-hydroxy-4(1H)-pyridone], which has less toxicity, by the $\mathrm{HCl}$ hydrolysis process (Tawata, 1990) or ruminants consuming Leucaena degrade mimosine to DHP by specific ruminal microorganisms (Jones and Lowry, 1984).

To date, much work on mimosine has concentrated on the reduction of this compound from Leucaena by the use of chemicals such as $\mathrm{FeCl}_{3}$ and $\mathrm{HCl}$ or by the degradation enzymes extracted from ruminant microorganisms (Soedarjo and Borthakur, 1998; Tawata, 1990). Silvane et al. (2001) examined the mimosine content in Leucaena seedlings and found the shoot had the greatest amount of mimosine. They observed that with mechanical damage applied to shoots, the quantity of mimosine was promoted locally. Salicylic acid in culture media stimulated mimosine accumulation in the seedling roots (Silvane et al., 2001). However, the regulation of mimosine in adult Leucaena plants as well as the exuding process of mimosine from plant parts of Leucaena was not clearly understood.

Mimosine has been evaluated as a major allelochemical in Leucaena, which is responsible for the strong allelopathic activity, and showed a suppressive impact on some tested plants and noxious fungi (Tawata, 1990). We proposed that mimosine should be extracted from Leucaena plants and be applied in the development of novel bioactive herbicides. Leucaena is very abundant in subtropical and tropical areas, with fast growth, providing a great amount of plant biomass. In addition, our laboratory has already developed a simple method to extract mimosine from Leucaena plants (Tawata, 1990). Therefore, the use of this allelochemical could make both agronomic and economic impacts. However, before utilizing this compound in agricultural practice, its regulative characteristic in the Leucaena plant, as well as its action in soil must be thoroughly understood. It was found that mimosine binds with the ferrous ion to form a mimosine-ferrous complex that was not toxic to the growth of mice and rats; although the same amounts of free mimosine did inhibit their growth (Lin and Ling, 1961). Mimosine chelates iron with a binding constant of $10^{36}$, which may be important in its mechanism of action (Katoh, 1972). Furthermore, mimosine inhibits the DNA synthesis of many DNA viruses through the inactivation of ribonucleotide reductase, and this suppression was reversible by iron. The amendment of iron or copper has also been shown to reverse the inhibitory effect of mimosine on DNA synthesis in Chinese hamster cells (Mosca et al., 1995). Spraying ferric chloride at $1.2 \%$ was reported to reduce the toxicity of Leucaena leaves on rabbit health (Gupta and Atreja, 1988). The incorporation of the ferric chloride solution reduces the toxicity of mimosine in animals; however, whether its harmful influence on plants decreases or not has not been documented yet. This clarification may be useful to lessen the soil sickness caused by mimosine in the soils grown with Leucaena.

Chemicals which are responsible for the allelopathic activity of a plant may be exploited as herbicidal, pesticidal or fungicidal compounds. The common allelochemicals from plants are generally secondary metabolites. Numerous allelochemicals are involved in the allelopathic activities of the allelopathic plants; such as phenolics, terpenoids, alkaloids, coumarins, tannins, flavonoids, steroids and quinines (Xuan et al., 2005). However, these compounds are available in low concentration in the most allelopathic plants. To achieve a significant suppression of weed or pest emergence, an interaction is needed for many allelochemicals, rather than a single substance. If a single compound responsible for the allelopathic activity of a plant could be isolated and identified, it would be a scientific breakthrough for developing bioactive herbicides. In fact, several compounds extracted from higher plants, such as cineole, benzoxazinones, quinolinic acid and leptospermones, have been applied in agricultural weed control with promising results (Benzoxazinones and Quinolinic acid by BASF, Germany; Cineole as Cinmethylene by Shell, USA: Letospermones as Triketones by Zeneca).

This research was carried out to clarify the quantity of mimosine in various plant parts, the exudate process of mimosine, the action of mimosine after penetrating into soil and to examine the possibility of using mimosine for biological reduction of weeds in cultivated soils. Simultaneously, an attempt at lowering the mimosine toxicity in the Leuceana plant, which would increase the use of this legume as cattle feed, was also conducted.

\section{MATERIALS AND METHODS}

\subsection{Mimosine}

The mimosine used in this experiment was purified in the Department of Bioscience and Biotechnology, Faculty of Agriculture, University of the Ryukyus, Japan, by following a simple method introduced by Tawata (1990). In this method, Leucaena leaves were boiled and the solution was filtered. Ultra-filtration was conducted at 4 atm at $30{ }^{\circ} \mathrm{C}, 700 \mathrm{rpm}$ equipped with a Filtron membrane. A column packed with acid form Amberlite IRA (technical grade) was employed and the resin was then washed with $2 \mathrm{~N} \mathrm{NH}_{4} \mathrm{OH}$ with the $\mathrm{pH}$ adjusted to 4.5-5.0. The structure of mimosine and its molecular weight (mol wt $=198$ ) were confirmed using Electron-Impact Ionization Mass Spectrometry (EI-MS) and Nuclear Magnetic Resonance (NMR) (Figs. 3, 4, respectively) as described in Tawata (1990).

\subsection{Leucaena plants}

Young and mature leaves and seeds were collected from Leucaena plants growing in nature around the University of the 


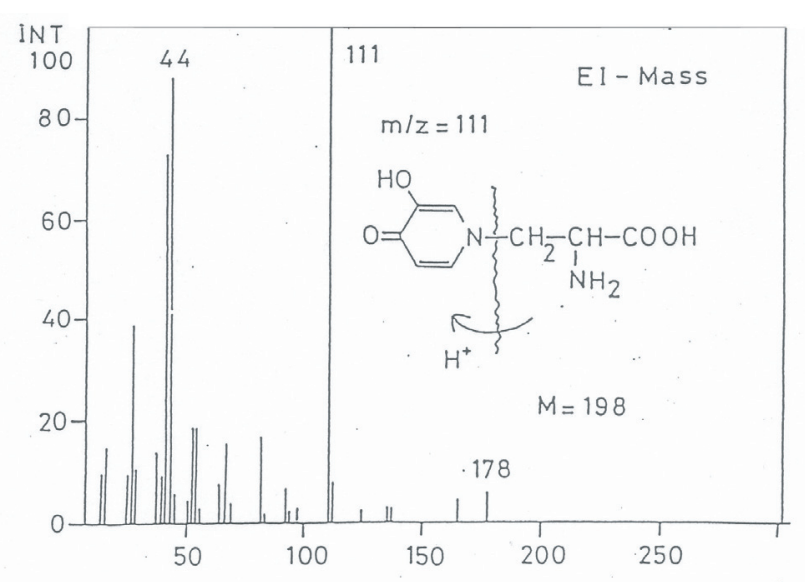

Figure 3. Mass spectrum of mimosine.

Ryukyus. In another trial, four common Leucaena varieties (Native, K72a, K8 and K28) in the region of Okinawa were grown in a greenhouse and their different plant parts were collected, which include: bark, xylems, xylem of roots, mature leaves, immature leaves, mature stems, young stems, hairy roots, cortex of roots, mature seed pods, immature seed pods, immature seeds, mature seeds, flowers and flower buds. Samples were cleaned with distilled water and used immediately.

\subsection{High performance liquid chromatography (HPLC)}

The HPLC (Nihonbunko, Japan) system includes an 880-PU pump and column (Fine pak Sil C18, Nihonbunko Company). The mobile phase employed was a mixed solution of $10 \mathrm{mM}$ potassium-dihydrogen phosphate, $10 \mathrm{mM}$ phosphoric acid, acetonitrile (45:45:10), and finally, $0.1 \%$ sodium 1-octanesulfonate was added to the mixture as the surface active agent. The flow rate was $1.5 \mathrm{~mL}$ per min. Mimosine was detected at a wavelength of $280 \mathrm{~nm}$.

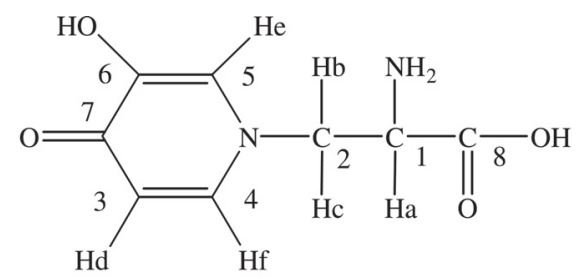

${ }^{13} \mathrm{C}-\mathrm{NMR}$

${ }^{1} \mathrm{H}-\mathrm{NMR}$

\begin{tabular}{|c|c|c|c|c|c|}
\hline & PPM & \multicolumn{2}{|c|}{ PPM } & \multicolumn{2}{|l|}{$\mathrm{Hz}$} \\
\hline 1 & $59.4 d$ & $\mathrm{Ha}$ & $3.65 q$ & $\mathrm{Jab}$ & 6.21 \\
\hline 2 & $63.8 \mathrm{t}$ & $\mathrm{Hb}$ & $4.01 \mathrm{q}$ & $\mathrm{Jbc}$ & 13.51 \\
\hline 3 & $115.0 d$ & $\mathrm{Hc}$ & $4.15 q$ & Jca & 5.40 \\
\hline 4 & $128.6 \mathrm{~d}$ & Hd & $6.40 \mathrm{~d}$ & Jdf & 6.21 \\
\hline 5 & $136.1 d$ & $\mathrm{He}$ & $7.12 \mathrm{~s}$ & & \\
\hline 6 & $160.2 \mathrm{~s}$ & Hf & $7.30 \mathrm{~d}$ & & \\
\hline 7 & $177.6 \mathrm{~s}$ & $\mathrm{NH} 2, \mathrm{OH}, \mathrm{COOH}$ & 4.96 & & \\
\hline 8 & $181.6 \mathrm{~s}$ & & & & \\
\hline
\end{tabular}

\subsection{Phytotoxic effects of mimosine on various plants}

Dilutions of 1, 10, 25, 50, 100 and $1000 \mathrm{mg} / \mathrm{L}$ of mimosine were made and tested for their influence on the germination and growth of Bidens pilosa L. var radiata Schertt (hairy beggarticks), Brassica rapa var. amplexicaulis (cabbage), Mimosa pudica L. (creeping grass), Leucaena leucocephala de Wit. (Leucaena), Lolium multiflorum L. (Italian ryegrass) and Phaseolus vulgaris L. var. humilis ALEF (kidney bean), respectively. Commercial seeds of B. rapa, M. pudica, L. multiflorum and $P$. vulgaris were used. Seeds of B. pilosa and Leucaena were collected from plants around the University of the Ryukyus. The seeds of Leucaena were treated in advance with distilled water at $80{ }^{\circ} \mathrm{C}$ for $2 \mathrm{~min}$ to stimulate germination. All seeds had a germinating percentage $>90 \%$ in a germination test before the experiment was carried out. Before use, Petri dishes were incubated at $160{ }^{\circ} \mathrm{C}$ for $30 \mathrm{~min}$ for sterilization. An aliquot of $10 \mathrm{~mL}$ of each solution was added to the Petri dish, and twenty seeds of the plants were sown in them, respectively. The treatments were incubated at $27^{\circ} \mathrm{C}$. After one week, germination and the lengths of the hypocotyl and radicle were calculated.

\subsection{Releasing of mimosine from seeds and leaves of Leucaena}

Seeds of Leucaena were immersed in hot water $\left(80^{\circ} \mathrm{C}\right)$ for 2 min to stimulate germination. Ten $\mathrm{g}$ of young and mature leaves and germinating seeds (270 seeds on average) of the legume were added to $100 \mathrm{~mL}$ of distilled water and kept at room temperature $\left(25^{\circ} \mathrm{C}\right)$. The distilled water was changed every $1 \mathrm{~h}$ and conducted constantly for a period of $6 \mathrm{~h}$. The releasing solution was filtered by filter papers and applied for HPLC in aliquots of $2 \mu \mathrm{L}$. In another trial, young leaves and germinating seeds were immersed in distilled water for $24 \mathrm{~h}$, and the distilled water was changed every $3 \mathrm{~h}$. The solution was injected into the HPLC system using similar conditions.

\subsection{Mimosine content in different parts of Leucaena}

The content of mimosine in different parts of Leucaena plants was determined by following a method introduced by
Figure 4. ${ }^{13} \mathrm{C}-\mathrm{NMR}$ and ${ }^{1} \mathrm{H}-\mathrm{NMR}$ data of mimosine. 
Tawata (1990). Two g of bark, xylems, xylem of roots, mature leaves, immature leaves, mature stems, young stems, hairy roots, cortex of roots, mature seed pods, immature seed pods, immature seeds, mature seeds, flowers and flower buds were freeze-dried and ground into powder with a Wiley's mill, and the mixture was then homogenized for $10 \mathrm{~min}$ by polytron with ice cooling. The obtained mixture of Leucaena was centrifuged at $12000 \mathrm{rpm}$ and the supernatant was filtered. The filtrate was adjusted to a volume of $100 \mathrm{~mL}$ by the addition of $0.1 \mathrm{~N} \mathrm{HCl}$, and the solution was then filtered and injected into the HPLC system in aliquots of $2 \mu \mathrm{L}$. The mimosine content was averaged by determining the mimosine quantities of the four Leucaena varieties.

Exuding of mimosine from different plant parts of Leucaena was also carried out. Ten $g$ of each sample were immersed in a volume of $100 \mathrm{~mL}$ of distilled water for $1 \mathrm{~h}$ at room temperature. The solution was filtered and injected into the HPLC system in aliquots of $2 \mu \mathrm{L}$.

\subsection{Penetration of mimosine into soil}

Soil from the Experimental Farm was taken into the laboratory and air-dried for 3 days and then was sieved to $<5 \mathrm{~mm}$. Thirty $\mathrm{g}$ of the soil was put into a Petri dish (diameter: $9 \mathrm{~cm}$ ). An aliquot of $10 \mathrm{~mL}$ mimosine at $2000 \mathrm{mg} / \mathrm{L}$ was added to the dish. In addition to that, a control was applied with $30 \mathrm{~g}$ of silica gel to compare the adsorption of mimosine with the treatments. At intervals of 1, 2, 3, 4 and 5 days, the soil was washed with $100 \mathrm{~mL}$ of distilled water. The solutions were filtered and injected into the HPLC system to measure the adsorption and decomposition quantity of mimosine in the soil.

In another trial, potting compost soil was used. The soil was put in a plastic pot (diameter: $22 \mathrm{~cm}, 3.6 \mathrm{~L}$ ) and placed outdoors. Three separate dilutions of 10,100 and $1000 \mathrm{mg} / \mathrm{L}$ of mimosine were prepared and the pots were watered with $2 \mathrm{~L}$ of each dilution. The control was adding an equal amount of tap water to each of them. After five days, seeds of B. rapa and Raphanus sativus were sown in the pots. On the first day, the pots were saturated with $500 \mathrm{~mL}$ of tap water, and the following days $200 \mathrm{~mL}$ of tap water was added. After three weeks, 50 plants of the two indicator plants were randomly selected. The length of hypocotyls, leaves, the width of the leaves, and the fresh weight of $B$. rapa and $R$. sativus was measured, respectively. Only measurements on root length of $R$. sativus were carried out because roots of $B$. rapa were easily fractured, resulting in an incorrect calculation. After drying at $100^{\circ} \mathrm{C}$ for $1 \mathrm{~h}$, and $60{ }^{\circ} \mathrm{C}$ for 1 week, the dry weight was determined.

\subsection{Detoxification for mimosine}

The effects of mimosine and $\mathrm{FeCl}_{3}$ were compared by using dilutions of $1,10,50$ and $100 \mathrm{mg} / \mathrm{L}$ on the emergence of $B$. rapa, using a similar method to the bioassay experiment. Furthermore, dilutions of mimosine and $\mathrm{FeCl}_{3}$ at 50 and $100 \mathrm{mg} / \mathrm{L}$ were also prepared, respectively. Afterwards, they were blended in the following ratio: $\mathrm{FeCl}_{3}$ : mimosine by $2: 8,4: 6,6: 4$ and $8: 2$, respectively. Ten $\mathrm{mL}$ of the mixture was added to the Petri dish (diameter: $9 \mathrm{~cm}$ ) lined with filter paper. Twenty seeds of similar B. rapa were placed in the dish. After one week, the impact on the length of hypocotyls and radicles of the tested plant was determined.

\subsection{Statistical analysis}

All experiments were conducted in a completely randomized design with three replicates. Data were analyzed using the SAS 6.12 version (SAS Institute, 1997) for ANOVA with the least significant difference (LSD) at a 0.05 probability level.

\section{RESULTS AND DISCUSSION}

\subsection{Phytotoxic effects of mimosine on various plants}

Table I shows that mimosine appeared to have a strong suppression of the length of radicles and hypocotyls of the six tested plants, although at the doses 1 and $10 \mathrm{mg} / \mathrm{L}$, mimosine promoted emergence of the six tested plants, except for $P$. vulgaris growth, which was inhibited by $30-40 \%$. At $50-1000 \mathrm{mg} / \mathrm{L}$, these indicator plants were strongly stunted by mimosine, and the growth of $B$. rapa was almost completely inhibited. At a concentration up to $100 \mathrm{mg} / \mathrm{L}$, mimosine did not show any inhibition of the length of radicles and hypocotyls of Leucaena, while it displayed a strong suppression of the emergence of other plants. Besides Leucaena, $M$. pudica is also a mimosine producer (Renz, 1936); therefore mimosine at a low concentration did not influence emergence of the two plants. Among the tested plants, B. pilosa and L. multiflorum were inhibited by mimosine at $25 \mathrm{mg} / \mathrm{L}$, and the inhibition was proportional to the applied dose of this compound, suggesting that mimosine may be effectively exploited as a herbicidal compound. However, the dose of mimosine applied to soil can cause great suppression of the target noxious weeds and should be carefully examined. Treatment time, the applied dose and the influences of soil $\mathrm{pH}$, minerals, chemicals and ions on the action of mimosine on weeds and crops need to be detailed.

\subsection{Releasing of mimosine from Leucaena}

Mimosine (Fig. 1) has long been known as an allelochemical produced by Leucaena, and the injury this legume caused the other plants in its surroundings is attributed to toxicity similar to mimosine (Tawata, 1990). Mimosine may enter soil through the Leucaena root, and the leaves decomposition. However, Leucaena grows in subtropical and tropical areas, which commonly have a great annual rainfall that may also lead to the exudates of mimosine from Leucaena plant parts to the soil. This contributes to the phenomenon of soil injury. Therefore, we studied the exuding mode of mimosine from Leucaena, which should be examined to clarify Leucaena's allelopathy.

Table II shows that young leaves of Leucaena gave the greatest amount of mimosine through exuding, compared with the mature leaves and seeds. However, no mimosine was detected in the solution obtained from mature leaves in this experiment. The seeds did not release any mimosine after the first $3 \mathrm{~h}$, while the young leaves gave $39.8 \mathrm{mg} / \mathrm{L}$ of mimosine. After $4 \mathrm{~h}$ of absorbing, $10.8 \mathrm{mg} / \mathrm{L}$ of mimosine was exuded from the seeds and increased to $43.5 \mathrm{mg} / \mathrm{L}$ after $6 \mathrm{~h}$, while the young leaves had $66.2 \mathrm{mg} / \mathrm{L}$ of mimosine. Table II indicates that both the 
Table I. Growth inhibitory activity of mimosine on growth of indicator plants (\%).

\begin{tabular}{|c|c|c|c|c|c|c|c|}
\hline \multirow[t]{2}{*}{ Plant species } & \multicolumn{7}{|c|}{ Concentration $(\mathrm{mg} / \mathrm{L})$} \\
\hline & 1 & 10 & 25 & 50 & 100 & 1000 & $\operatorname{LSD}(0.05)$ \\
\hline \multicolumn{8}{|c|}{ Radicle } \\
\hline Brassica rapa & $-10.4 \mathrm{~d}$ & $2.7 \mathrm{~b}$ & $89.4 \mathrm{a}$ & $91.3 \mathrm{a}$ & $94.8 \mathrm{a}$ & $96.0 \mathrm{a}$ & 9.1 \\
\hline Phaseolus vulgaris & $-2.2 \mathrm{c}$ & $41.0 \mathrm{a}$ & $37.3 \mathrm{c}$ & $46.3 \mathrm{~d}$ & $72.4 \mathrm{~b}$ & $83.7 \mathrm{~b}$ & 7.2 \\
\hline Bidens pilosa & $-21.7 \mathrm{e}$ & $2.4 \mathrm{~b}$ & $44.1 \mathrm{c}$ & $38.0 \mathrm{~d}$ & $45.2 \mathrm{~d}$ & $62.0 \mathrm{~cd}$ & 11.4 \\
\hline Mimosa pudica & $-34.0 f$ & $-17.8 \mathrm{c}$ & $-6.3 g$ & $17.3 \mathrm{e}$ & $40.1 \mathrm{~d}$ & $53.9 \mathrm{~d}$ & 12.3 \\
\hline Lolium multiflorum & $1.4 \mathrm{c}$ & $-24.1 \mathrm{~d}$ & $36.5 \mathrm{c}$ & $74.6 \mathrm{~b}$ & $89.5 \mathrm{a}$ & $97.8 \mathrm{a}$ & 13.1 \\
\hline Leucaena leucocephala & $7.9 \mathrm{~b}$ & $-78.4 \mathrm{f}$ & $-7.4 \mathrm{~g}$ & $1.4 \mathrm{f}$ & $2.4 \mathrm{~g}$ & $56.4 \mathrm{~cd}$ & 12.7 \\
\hline \multicolumn{8}{|c|}{ Hypocotyl } \\
\hline Brassica rapa & $-3.3 \mathrm{c}$ & $-2.9 b c$ & $71.2 b$ & $83.8 \mathrm{a}$ & $92.8 \mathrm{a}$ & $98.0 \mathrm{a}$ & 10.5 \\
\hline Phaseolus vulgaris & $9.8 \mathrm{~b}$ & $32.4 \mathrm{a}$ & $27.9 \mathrm{~d}$ & $16.4 \mathrm{e}$ & $44.2 \mathrm{~d}$ & $63.9 \mathrm{c}$ & 7.7 \\
\hline Bidens pilosa & $-13.1 \mathrm{~d}$ & $9.4 \mathrm{~b}$ & $44.1 \mathrm{c}$ & $24.1 \mathrm{e}$ & $40.6 \mathrm{~d}$ & $51.6 \mathrm{~d}$ & 6.9 \\
\hline Mimosa pudica & $-28.3 \mathrm{e}$ & $-12.0 \mathrm{c}$ & $17.6 \mathrm{e}$ & $60.2 \mathrm{c}$ & $60.2 \mathrm{c}$ & $61.3 \mathrm{~cd}$ & 8.2 \\
\hline Lolium multiflorum & $16.4 \mathrm{a}$ & $-33.0 \mathrm{~d}$ & $8.1 \mathrm{f}$ & $24.0 \mathrm{e}$ & $31.1 \mathrm{e}$ & $64.7 \mathrm{c}$ & 6.4 \\
\hline Leucaena leucocephala & $-3.3 \mathrm{c}$ & $-56.4 \mathrm{e}$ & $-1.2 \mathrm{~g}$ & $2.8 \mathrm{f}$ & $11.5 \mathrm{f}$ & $61.1 \mathrm{~cd}$ & 5.9 \\
\hline $\operatorname{LSD}(0.05)$ & 4.9 & 9.3 & 7.8 & 8.6 & 8.7 & 8.9 & 4.9 \\
\hline
\end{tabular}

Columns with the same letter are not significantly different $(P<0.05)$.

Means indicate inhibitory percentage over the respective control.

Means with (-) indicate stimulatory percentage over the respective control.

Table II. The releasing of mimosine at $25^{\circ} \mathrm{C}$ from leaves and seeds of Leucaena $(\mathrm{mg} / \mathrm{L})$ for every $1 \mathrm{~h}$.

\begin{tabular}{lrrrrrr}
\hline Plant materials & \multicolumn{5}{c}{ Time $(\mathrm{h})$} \\
\hline & 1 & 2 & 3 & 4 & 5 & 6 \\
Young leaves & $16.5 \mathrm{a}$ & $30.1 \mathrm{a}$ & $39.8 \mathrm{a}$ & $38.0 \mathrm{a}$ & $51.6 \mathrm{a}$ & $66.2 \mathrm{a}$ \\
Mature leaves & $0.0 \mathrm{~b}$ & $0.0 \mathrm{~b}$ & $0.0 \mathrm{~b}$ & $0.0 \mathrm{c}$ & $0.0 \mathrm{c}$ & $0.0 \mathrm{c}$ \\
Seeds & $0.0 \mathrm{~b}$ & $0.0 \mathrm{~b}$ & $0.0 \mathrm{~b}$ & $10.8 \mathrm{~b}$ & $24.5 \mathrm{~b}$ & $53.5 \mathrm{~b}$ \\
LSD $(0.05)$ & 3.1 & 5.1 & 5.4 & 5.4 & 5.8 & 6.1 \\
\hline
\end{tabular}

Columns with the same letter are not significantly different $(P<0.05)$.

Means indicate inhibitory percentage over the respective control.

young leaves and the seeds of Leucaena release mimosine through soaking water, but the quantity of mimosine released from the young leaves was greater than that of the seeds, and the mimosine exudate was proportional to the soaking time. However, mimosine was not released from mature leaves of Leucaena.

Sampling intervals were increased to 3-hourly for a period of $24 \mathrm{~h}$, and were applied to young leaves and seeds of this legume (Tab. III). Similar to Table II, the amount of mimosine exuding from the young leaves was about 2 times greater than from the seeds. Although mimosine was released after every $3 \mathrm{~h}$ of continuous soaking, the quantity of mimosine was about 3 times lower than by changing the water every $1 \mathrm{~h}[19.8$ and $12.6 \mathrm{mg} / \mathrm{L}$ compared with 66.2 and $43.5 \mathrm{mg} / \mathrm{L}$ for the young leaves and seeds, respectively (Tabs. II and III)]. Furthermore, the amount of mimosine released from the young leaves and seeds was proportional to the total time of soaking. This observation suggests that in areas with heavy rainfall, a great amount of mimosine exudes from young leaves and seeds of Leucaena plants. This may lead to the inhibition of other plants growing in the surroundings of Leucaena and may reduce the mimosine in Leucaena.

\subsection{Mimosine content in different parts of Leucaena}

The amount of mimosine contained in various plant parts of Leucaena was examined and is presented in Table IV. Young leaves had the highest amount of mimosine $(2.66 \%$ of dry weight) and the lowest amount was in xylems $(0.11 \%)$. Mature leaves did not contain high quantity of mimosine $(0.47 \%)$, whereas mature seeds were shown to accumulate the second greatest quantity of mimosine, as shown in Table IV. Flowers 
Table III. The releasing of mimosine at $25{ }^{\circ} \mathrm{C}$ from leaves and seeds of Leucaena $(\mathrm{mg} / \mathrm{L})$ for every $3 \mathrm{~h}$.

\begin{tabular}{|c|c|c|c|c|c|c|c|c|}
\hline \multirow[t]{2}{*}{ Plant materials } & \multicolumn{8}{|c|}{ Time (h) } \\
\hline & 3 & 6 & 9 & 12 & 15 & 18 & 21 & 24 \\
\hline Young leaves & $8.1 \mathrm{a}$ & $19.8 \mathrm{a}$ & $24.5 \mathrm{a}$ & $39.7 \mathrm{a}$ & $55.5 \mathrm{a}$ & $68.3 \mathrm{a}$ & $83.1 \mathrm{a}$ & $97.6 \mathrm{a}$ \\
\hline Seeds & $5.5 b$ & $12.6 \mathrm{~b}$ & $18.5 b$ & $21.8 b$ & $29.1 b$ & $34.5 b$ & $41.2 \mathrm{~b}$ & $45.7 b$ \\
\hline LSD (0.05) & 1.2 & 3.4 & 3.5 & 4.8 & 5.2 & 9.1 & 9.3 & 9.5 \\
\hline
\end{tabular}

Columns with the same letter are not significantly different $(P<0.05)$.

Means indicate inhibitory percentage over the respective control.

Table IV. Mimosine content in different parts of Leucaena and the exuded amount of mimosine immersed in water for $1 \mathrm{~h}$.

\begin{tabular}{lcc}
\hline Plant parts & Mimosine content $(\%)$ & Exuded amount (mg/L) \\
\hline Xylems & 0.11 & 0.00 \\
Xylem of roots & 0.18 & 0.16 \\
Mature leaves & 0.47 & 0.00 \\
Mature stems & 0.54 & 0.00 \\
Hairy roots & 0.57 & 0.48 \\
Cortex of roots & 0.66 & 0.52 \\
Mature seed pods & 0.67 & 0.00 \\
Bark & 0.68 & 0.00 \\
Immature seed pods & 0.88 & 3.68 \\
Immature seeds & 1.00 & 4.11 \\
Flowers & 1.17 & 4.84 \\
Flower buds & 1.34 & 5.58 \\
Young stems & 1.50 & 6.16 \\
Mature seeds & 2.38 & 1.79 \\
Young leaves & 2.66 & 11.05
\end{tabular}

Mimosine content was placed by increasing order of percentage found in plant parts of Leucaena.

Mimosine content was averaged over the four Leucaena varieties (Native, K72a, K8 and K28).

and flower buds obtained 1.17 and $1.34 \%$ of mimosine, respectively. The roots had low contents of mimosine (xylem, hair and cortex of roots: $0.18,0.57$ and $0.66 \%$, respectively). The amount of mimosine in the bark was lower $(0.68 \%)$ than the amount in the immature seed pods, and immature and mature seeds $(0.88,1.00$ and $2.38 \%$, respectively).

The results prove that every plant part of Leucaena produces mimosine and this toxic amino acid accumulated in the greatest amounts in the young leaves and mature seeds. This is the greatest challenge for using Leucaena leaves, because mimosine is toxic to animals, causing the reduction of growth and general ill health when Leucaena leaves are ingested (Jones, 1979). This is the first report describing the quantity of mimosine in various plant parts of Leucaena, which calculates the average amount of mimosine measured in the four common Leucaena varieties in Okinawa (Native, K72a, K8 and K28). There has been previous research that documented the amount of mimosine in leaves (Brewbaker and Hylin, 1965; Prasad, 1995; Soedarjo and Borthakur, 1998) and roots (Soedarjo, 1998).
However, the mimosine in specific plant parts, such as xylems, root xylems, hairy roots, cortex of roots, mature seed pods, mature stems, bark, immature seeds, flowers and flower buds were not elucidated. The findings in Table IV note that mature seeds can provide a great quantity of mimosine $(2.38 \%)$ and may be a useful source akin to the young leaves of Leucaena for the purification of mimosine or for biological weed suppression.

The process of exuding mimosine from these plant parts of Leucaena was also examined (Tab. IV). It was shown that the quantity of mimosine exuded from this legume was proportional to the plant's development period. The younger plant parts gave greater exudates of mimosine than the mature parts. For instance, mature seeds had about two times the amount of mimosine of the immature seeds and their pods, but their transuded mimosine was about two times less than immature seeds. No mimosine was released from the xylems, mature leaves, mature stems, mature seed pods or bark. The flowers and flower buds provided 4.84 and $5.58 \mathrm{mg} / \mathrm{L}$ of mimosine, respectively, whereas the young leaves gave the greatest mimosine through exuding $(11.05 \mathrm{mg} / \mathrm{L})$. The hair and cortex of Leucaena roots gave 0.48 and $0.52 \mathrm{mg} / \mathrm{L}$ of mimosine after soaking for $1 \mathrm{~h}$, denoting that mimosine may also be exuded from the plant roots to the soil during rain. However, the greatest amount of mimosine releasing from the plant may originate from the young leaves.

\subsection{Adsorption and decomposition of mimosine in soil}

Treatment with silica gel yielded the greatest concentration of mimosine $(14.07 \mathrm{mg} / \mathrm{L})$ and neither adsorption nor decomposition of mimosine was detected (Tab. V). During 1-5 days of treatment, the concentration of mimosine in the soil was not significantly different $(5.51-5.87 \mathrm{mg} / \mathrm{L})$. The adsorption of mimosine into the soil was $58.30-60.82 \%$ and no marked difference among treatments was found. However, the percentage of decomposed mimosine was inversely proportional to the time after amendment. One day after treatment, $5.30 \%$ of mimosine was decomposed, after three days it was $2.52 \%$ and on the fifth day, it was only $0.16 \%$. Thus, it was shown that the concentration and adsorption of mimosine in soil were not significantly different among treatment times (washed with $100 \mathrm{~mL}$ of distilled water at 1,2,3,4 and 5 days after treatment). After mimosine was added to the soil, earlier washing with water led to the greatest decomposition amount of mimosine, which suggests that the decomposing process may be proportional to the water content in soil. In tropical areas, where there 
Table V. Adsorption and decomposition of mimosine in soil.

\begin{tabular}{lccc}
\hline $\begin{array}{l}\text { Treatment } \\
(\mathrm{d})\end{array}$ & $\begin{array}{c}\text { Concentration } \\
(\mathrm{mg} / \mathrm{L})\end{array}$ & $\begin{array}{c}\text { Adsorption } \\
(\%)\end{array}$ & $\begin{array}{c}\text { Decomposition } \\
(\%)\end{array}$ \\
\hline Silica gel & $14.07 \mathrm{a}$ & $0.00 \mathrm{~b}$ & $0.00 \mathrm{c}$ \\
1 & $5.55 \mathrm{~b}$ & $60.54 \mathrm{a}$ & $5.30 \mathrm{a}$ \\
2 & $5.87 \mathrm{~b}$ & $58.30 \mathrm{a}$ & - \\
3 & $5.51 \mathrm{~b}$ & $60.82 \mathrm{a}$ & $2.52 \mathrm{~b}$ \\
4 & $5.65 \mathrm{~b}$ & $59.87 \mathrm{a}$ & - \\
5 & $5.62 \mathrm{~b}$ & $60.03 \mathrm{a}$ & $0.16 \mathrm{c}$ \\
LSD $(0.05)$ & 2.3 & 11.2 & 0.8 \\
\hline
\end{tabular}

- : measurement was not conducted.

Columns with the same letter are not significantly different $(P<0.05)$.

Means indicate inhibitory percentage over the respective control.

is heavy rainfall, a great amount of mimosine could be released from Leucaena [almost all from young plant parts (Tab. IV)].

Table VI shows the impacts of soil treated with different dilutions of mimosine on the two indicator plants (B. rapa and $R$. sativus, respectively). Mimosine appeared to have detrimental effects on the growth of the two plants. At $10 \mathrm{mg} / \mathrm{L}$, mimosine promoted the growth of these plants, except for the stem length of $B$. rapa. On the contrary, the dry weight and leaf elongation of $R$. sativus were slightly inhibited. At $100 \mathrm{mg} / \mathrm{L}$, dry weights of $B$. rapa and $R$. sativus were inhibited by 5.1 and $7.8 \%$, but at $1000 \mathrm{mg} / \mathrm{L}$ it was extended to 30.3 and $49.3 \%$, respectively. In addition, at $1000 \mathrm{mg} / \mathrm{L}$, mimosine gave a greater suppression of leaf growth of $B$. rapa than $R$. sativus. The root diameter of $R$. sativus was inhibited by $35 \%$. The results in Table VI point out that the soil incorporated with mimosine exhibited an inhibition of the growth of the two tested plants and the suppressive magnitude was proportional to the applied concentrations. Young leaves of Leucaena contain a great quantity of mimosine (2.66\% of dry weight) and mimosine is an allelochemical showing strong phytotoxic action on plant growth, which suggests that the utilization of young Leucaena leaves as a natural herbicide is very promising.

\subsection{Phytotoxic action of mimosine, $\mathrm{FeCl}_{3}$, and their mixture}

Table VII demonstrates that at $1-10 \mathrm{mg} / \mathrm{L}$, both mimosine and $\mathrm{FeCl}_{3}$ promoted elongation of B. rapa. $\mathrm{FeCl}_{3}$ gave the greatest stimulation to the radicle of the plant $(25.7 \%$ of promotion). However, the radicle of $B$. rapa was slightly inhibited by mimosine $(2.7 \%)$. At $50-100 \mathrm{mg} / \mathrm{L}$, mimosine almost completely inhibited the plant root (about $80-90 \%$ of inhibition), whereas $\mathrm{FeCl}_{3}$ had less toxicity. The strongest influence of $\mathrm{FeCl}_{3}$ was at $100 \mathrm{mg} / \mathrm{L}$ with the length of the $B$. rapa radicle (69.4\% of suppression). Similar to the results in Table VII, mimosine also exhibited a great detrimental impact on the growth of $B$. rapa, shown at two concentrations of 50 and $100 \mathrm{mg} / \mathrm{L}$ (Tab. VIII). At $50 \mathrm{mg} / \mathrm{L}$, mimosine reduced the plant emergence by about $80-90 \%$ and more than $90 \%$ by $100 \mathrm{mg} /$ $\mathrm{L}$, while $\mathrm{FeCl}_{3}$ slightly promoted the length of $B$. rapa hypocotyls and inhibited the emergence of this plant by about $20-70 \%$ (Tab. VIII).

Different mixtures of $\mathrm{FeCl}_{3}$ and mimosine were prepared as shown in Table VIII. It was found that the toxicity of mimosine was reduced when blended with $\mathrm{FeCl}_{3}$ solution. Every mixture of the two solutions had a lower suppressive impact than either mimosine or $\mathrm{FeCl}_{3}$ alone on $B$. rapa. The mixture of $\mathrm{FeCl}_{3}$ :mimosine $=4: 6$ exhibited the lowest toxicity on plant growth, and it was the most effective among the mixtures of either $8: 2$ or $2: 8$, and $6: 4$ of $\mathrm{FeCl}_{3}$ :mimosine (Tab. VIII). The two blends of $8: 2$ and $2: 8$, even though they had a lesser suppressive magnitude than mimosine dilutions, still exhibited an inhibition of growth of the tested plants.

The observations in Tables VII and VIII show that both mimosine and $\mathrm{FeCl}_{3}$ exhibited adverse influences on emerging in B. rapa; however, their mixtures obtained a lower phytotoxic action on the plant. The ratio of $\mathrm{FeCl}_{3}$ :mimosine $=4: 6$ did not show toxicity and promoted plant growth, specifying that this ratio may be used for either reducing the toxicity of mimosine in Leucaena leaves to provide animals with a safer feed, or decreasing the soil toxicity problem caused by mimosine in the areas where Leucaena grows.

Table VI. Growth percentage of Brassica rapa and Raphanus sativus in soil treated with mimosine.

\begin{tabular}{|c|c|c|c|c|c|c|}
\hline \multirow[t]{3}{*}{ Plant parts } & \multicolumn{6}{|c|}{ Treated soil (mg/L) } \\
\hline & \multicolumn{3}{|c|}{$\mathrm{A}$} & \multicolumn{3}{|c|}{ B } \\
\hline & 10 & 100 & 100 & 10 & 100 & 100 \\
\hline Stem length & $8.0 \mathrm{a}$ & $10.5 \mathrm{c}$ & $44.1 \mathrm{a}$ & - & - & - \\
\hline Leaf length & $-6.8 b$ & $19.7 \mathrm{a}$ & $27.1 \mathrm{~b}$ & $4.4 \mathrm{~b}$ & $6.5 b$ & $10.0 \mathrm{c}$ \\
\hline Leaf width & $-11.1 b$ & $9.8 \mathrm{c}$ & $20.0 \mathrm{c}$ & $-3.0 \mathrm{~d}$ & $7.1 \mathrm{~b}$ & $3.6 \mathrm{~d}$ \\
\hline Fresh weight & $-18.6 c$ & $18.5 b$ & $42.8 \mathrm{a}$ & $-1.7 \mathrm{c}$ & $14.7 \mathrm{a}$ & $49.3 \mathrm{a}$ \\
\hline Dry weight & $-20.7 \mathrm{c}$ & $5.1 \mathrm{~d}$ & $30.3 b$ & $12.1 \mathrm{a}$ & $7.8 \mathrm{~b}$ & $49.3 \mathrm{a}$ \\
\hline Root diameter & - & - & - & $-20.6 e$ & $-12.7 \mathrm{c}$ & $35.0 \mathrm{~b}$ \\
\hline LSD (0.05) & 5.1 & 3.2 & 4.4 & 3.8 & 4.6 & 5.7 \\
\hline
\end{tabular}

A: B. rapa, B: R. sativus.

- : measurement was not conducted.

Columns with the same letter are not significantly different $(P<0.05)$.

Means indicate inhibitory percentage over the respective control.

Means with (-) indicate stimulatory percentage over the respective control. 
Table VII. Effects of $\mathrm{FeCl}_{3}$ and mimosine on growth of Brassica rapa $(\%)$.

\begin{tabular}{lcccc}
\hline $\begin{array}{l}\text { Concentration } \\
(\mathrm{mg} / \mathrm{L})\end{array}$ & \multicolumn{2}{c}{$\mathrm{FeCl}_{3}$} & \multicolumn{2}{c}{ Mimosine } \\
\cline { 2 - 5 } & Radicle & Hypocotyl & Radicle & Hypocotyl \\
\hline 1 & $-25.7 \mathrm{~d}$ & $-7.6 \mathrm{c}$ & $-10.7 \mathrm{c}$ & $-3.3 \mathrm{~b}$ \\
10 & $-2.6 \mathrm{c}$ & $-6.9 \mathrm{c}$ & $2.7 \mathrm{~b}$ & $-2.9 \mathrm{~b}$ \\
50 & $29.5 \mathrm{~b}$ & $9.7 \mathrm{ab}$ & $91.3 \mathrm{a}$ & $83.8 \mathrm{a}$ \\
100 & $69.4 \mathrm{a}$ & $11.8 \mathrm{a}$ & $94.8 \mathrm{a}$ & $92.8 \mathrm{a}$ \\
LSD (0.05) & 5.5 & 2.2 & 8.1 & 9.2 \\
\hline
\end{tabular}

Columns with the same letter are not significantly different $(P<0.05)$. Means indicate inhibitory percentage over the respective control.

Means with (-) indicate stimulatory percentage over the respective control.

The findings in this study repeatedly demonstrated that mimosine is responsible for the allelopathic activity in Leucaena. This non-protein amino acid exhibited a strong reaction to various plants and weeds, suggesting that this compound may be utilized as a leading herbicidal compound for the development of bioactive herbicides. Mimosine was found in all plant parts of Leucaena, including its roots, stems, bark, flowers, seeds and leaves, and the quantity of mimosine varied among the plant parts. In general, the young plant parts provided a greater amount of mimosine than the mature parts, except for the mature seeds, which gave the second greatest amount of mimosine ( $2.38 \%$ of dry weight), and was only less than the amount from the young leaves, which had the largest quantity of mimosine (2.66\% of dry weight) (Tab. IV). It was also shown that younger plant parts exuded a greater amount of mimosine than the mature parts through soaking. However, Leucaena seeds also provided a great quantity of mimosine exudates. Since mimosine is released, about $60 \%$ of it was adsorbed in soil, resulting in strong suppression of the plants grown on the mimosine soil. This could explain the great reduction of weeds in soil incorporated with Leucaena leaves (Hong et al., 2004). The mixture of $\mathrm{FeCl}_{3}$ and mimosine at the ratio of $4: 6$ is the most ideal way to lessen the toxicity of mimosine. There are some other ways to reduce the toxicity of mimosine in Leucaena, such as using mimosine degradation enzymes from bacteria (Jones and Lowry, 1984) or through the breeding of Leucaena varieties.

Leucaena trees are widely distributed in the subtropics and tropics, adapt to many weather and soil conditions and can provide a great amount of green biomass. In Southeast Asia, Leucaena plants are commonly used as green hedges to prevent soil erosion and their plant materials are incorporated into soil for soil enrichment (Hong et al., 2003, 2004). In our previous work, a wide variety of screenings for plants with strong allelopathic potential in Southeast Asia and Japan was conducted, and thirty species that exhibited the greatest allelopathic potential among the hundreds of screened species were selected, including Leucaena (Hong et al., 2003). Afterwards, Leucaena plants were dried and applied to a paddy field at 1-2 tons/ha, giving a $70 \%$ weed biomass reduction and an increased rice yield of $20 \%$ (Hong et al., 2004). However, a dosage of 1-2 tons/ha caused heavy fieldwork and did not meet current agricultural produc-
Table VIII. Effects of $\mathrm{FeCl}_{3}$, mimosine, and their mixture on the growth of Brassica rapa as compared with the respective control.

\begin{tabular}{lcccc}
\hline Treatments & \multicolumn{3}{c}{ Concentration $(\mathrm{mg} / \mathrm{L})$} \\
& \multicolumn{3}{c}{50} & \multicolumn{2}{c}{100} \\
\cline { 2 - 5 } & Radicle & Hypocotyl & Radicle & Hypocotyl \\
\hline $\mathrm{FeCl}_{3}$ & $20.6 \mathrm{c}$ & $-1.4 \mathrm{~b}$ & $68.5 \mathrm{~b}$ & $21.7 \mathrm{~b}$ \\
$\mathrm{Mimosine}_{2}$ & $90.2 \mathrm{a}$ & $79.6 \mathrm{a}$ & $94.7 \mathrm{a}$ & $93.6 \mathrm{a}$ \\
$2: 8^{*}$ & $44.1 \mathrm{~b}$ & $-2.9 \mathrm{bc}$ & $77.0 \mathrm{~b}$ & $30.2 \mathrm{~b}$ \\
$4: 6$ & $-28.3 \mathrm{e}$ & $-21.3 \mathrm{~d}$ & $-0.8 \mathrm{e}$ & $-4.8 \mathrm{c}$ \\
$6: 4$ & $0.0 \mathrm{~d}$ & $-13.3 \mathrm{~cd}$ & $32.3 \mathrm{~d}$ & $-1.6 \mathrm{c}$ \\
$8: 2$ & $6.5 \mathrm{~d}$ & $-14.3 \mathrm{~cd}$ & $57.0 \mathrm{c}$ & $22.3 \mathrm{~b}$ \\
$\mathrm{LSD}(0.05)$ & 13.1 & 14.5 & 10.9 & 10.7 \\
\hline
\end{tabular}

* Ratio of $\mathrm{FeCl}_{3}$ :mimosine.

Columns with the same letter are not significantly different $(P<0.05)$.

Means indicate inhibitory percentage over the respective control.

Means with (-) indicate stimulatory percentage over the respective control.

tion needs, due to shortage of the labor force (Khanh et al., 2005). Therefore, mimosine from Leucaena should be purified and used as a bioactive compound for controlling weeds and pests. In addition, Leucaena has a fast growth rate and can yield a great amount of young leaves. With our laboratory's simple method of purifying mimosine from Leucaena leaves, the use of this compound could bring both agronomic and economic benefits.

However, the evidence that the incorporation of Leucaena plant materials into cultivated soils can strongly minimize weed emergence, and that mimosine is a major constituent of Leucaena and responsible for the herbicidal activity of the plant, is still not known by local farmers. This fact should be extensively communicated to farmers by agricultural extension workers. Furthermore, how Leucaena biomass is applied to soils, and the times and dose of incorporation of the plants that could result in maximum weed reduction, need to be verified carefully before starting use of Leucaena for biological weed control in wide areas. The extraction of mimosine from Leucaena plants for the development of bioactive herbicides is very promising. Simultaneously, since mimosine content is lowered, Leucaena leaves will be a safer feed for cattle.

The examination of the kinetics of adsorption and degradation of a compound in soil is necessary to determine its potential use as a pesticide in agricultural practices. Understanding the fate of a potent herbicide after entering into soil helps to clarify its mode of actions against target plants as well as its influence (both harmful and beneficial) on the environment. Adsorption equilibriums of many chemicals onto soils have been approximated by Henry equations, and their adsorption coefficients are normalized against the organic carbon content of the soils, and adsorption constants based on the organic carbon $K_{\mathrm{OC}}$ are obtained (Kanazawa, 1989; Lyman, 1990; Weber, 1994). The OECD recommends a requirement to obtain the values of $K_{\mathrm{OC}}$ as an important parameter for simple organic compounds (OECD, 1986). Mimosine is a non-protein amino acid and it may be easily degraded after penetrating into soils by soil factors such as nutrients, minerals, $\mathrm{pH}$ and microbes. Therefore, 
examining the fate of mimosine in different soils measured by standard kinetic parameters should be carried out in future research to estimate the potential use of mimosine as a bio-pesticide in agricultural practices.

\section{REFERENCES}

Brewbaker J.L., Hylin J.W. (1965) Variation in mimosine content among Leucaena species and related mimosaceae, Crop Sci. 5, 348-349.

Crounse R.J., Maxwell J.D., Blank H. (1962) Inhibition of growth of hair by mimosine, Nature 194, 194-195.

Gilbert D.M., Neilson A., Miyazawa H., Depamphilis M.L, Gupta H.K., Altreja P.P. (1998) Influence of ferric chloride treated Leucaena leucocephala on metabolism of mimosine and 3-hydroxy-4 (1H)pyridone in growing rabbits, Anim. Feed Sci. Tech. 4, 45-55.

Gupta H.K., Atreja P.P. (1988) Influence of ferric chloride treated Leucaena leucocephala on metabolism of mimosine and 3-hydroxy$4(1 \mathrm{H})$-pyridone in growing rabbits, Anim. Feed Sci. Tech. 74, 4555 .

Hegarty M.P., Schinkel P.G., Court T.D. (1964) Reaction of sheep to the consumption of Leucaena glauca Benth. and to its toxic principle mimosine, Aust. J. Agric. Res. 15, 153-167.

Hong N.H., Xuan T.D., Tsuzuki E., Terao H., Matsuo M., Khanh T.D. (2003) Screening for allelopathic potential of higher plants from Southeast Asia, Crop Prot. 22, 829-836.

Hong N.H., Xuan T.D., Tsuzuki E., Khanh T.D. (2004) Paddy weed control by higher plants from Southeast Asia, Crop Prot. 23, 255-261.

Jones R.J. (1979) The value of Leucaena leucocephala as a feed for ruminants in the tropics, World Anim. Rev. 31, 13-23.

Jones R.J., Lowry J.B. (1984) Australian goats detoxify the goitrogen 3 hydroxy-4 $(1 \mathrm{H})$ pyridone (DHP) after ruminal infusion from an Indonesian goat, Experientia 40, 1435-1436.

Kanazawa J. (1989) Relationship between the soil sorption constants for pesticides and their physicochemical properties, Environ. Toxicol. Chem. 8, 477-484.

Katoh S., Toyama J., Kodama K., Kamiya K., Akita T., Abe T. (1972) Protective action of iron-chelating agents (catechol, mimosine, diferoxamine, and kojic acid) against ischemia-reperfusion injury of isolated neonatal rabbit heart, Eur. Surg. Res. 24, 349-355.

Khanh T.D., Chung I.M., Xuan T.D., Tawata S. (2005) The exploitation of crop allelopathy in sustainable agricultural production, J. Agron. Crop Sci. 191, 172-184.
Khanna K.K., Lavin M.F. (1993) Ionizing radiation and UV induction of P53 protein by different pathways in ataxia-telangiectasia cells, Oncogene 8, 3307-3312.

Kohili R.K., Batish D., Singh H.P. (1998) Allelopathy and its implications in agroecosystems, J. Crop Product. 1, 169-202.

Lin J.Y., Ling K.H. (1961) Studies on free amino acids in the free seeds of Leucaena glauca Benth. III. Biological study on mimosine, J. Formos. Med. Assoc. 60, 657-664.

Lyman W.J. (1990) Adsorption coefficients for soils and sediments, in: Reehl W.F., Rosenblatt D.H. (Eds.), Handbook of chemical property estimation methods, Chap. 4, American Chemical Society, Washington, DC.

Mosca P.J., Lin H.B., Hamlin J.L. (1995) Mimosine, a novel inhibitor of DNA replication binds to a $50 \mathrm{kDa}$ protein in Chinese hamster cell, Nucleic Acids Res. 23, 261-268.

Organization for Economic Co-operation and Development (OECD) (1986) Guidelines for testing chemical, Guideline 106: Sorption/ Desorption, Paris, France.

Prasad M.N.V. (1995) Analysis of Leucaena mimosine, Acacia tannins and total phenols by near infrared reflectance spectroscopy, Biomass Bioenerg. 8, 203-205.

Renz J. (1936) Mimosine, Physiol. Chem. 244, 153-158.

Rice E.L. (1984) (Ed.) Allelopathy, 2nd ed., Academic Press, Orlando, USA.

Soedarjo M., Borthakur D. (1998) Mimosine, a toxin produced by the tree-legume Leucaena provides a nodulation competition advantage to mimosine-degrading Rhizobium strains, Soil Biol. Biochem. $30,1605-1613$.

Silvane V., Arthur G.F., Rafael C.D., Alfredo G.F. (2001) Regulation of mimosine accumulation in Leucaena leucocephala seedlings, Plant Sci. 161, 597-604.

Tawata S. (1990) Effective reduction and extraction of mimosine from Leucaena and the potential for its use as a lead compound of herbicides, in: Casida J.E. (Ed.), Pesticide and Alternatives, Elsevier Science Publishers, Amsterdam, pp. 541-544.

Xuan T.D., Tawata S., Khanh T.D., Chung I.M. (2005) Biological control of weeds and plants pathogens in paddy rice by exploiting plant allelopathy: an overview, Crop Prot. 24, 197-206.

Weber J.B. (1994) Properties and behavior of pesticide movement into ground water, in: Honeycutt R.C. (Ed.), Mechanisms of pesticide movement into ground water, Chap. 2, Lewis Publishers, Boca Roton, FL, pp. 15-41. 